УдК 339.187: 608.1

M. Abbaszade,

PbD in Economics, Doctoral candidate, Institute of Economics of ANAS, c. Baku, Azerbaijan Republic

ORCID ID: 0000-0002-1725-5777

DOI: $10.32702 / 2306-6814.2021 .6 .17$

\title{
THE MAIN FEATURES OF MODERN REGIONAL DEVELOPMENT POLICY
}

\author{
M. Аббасзаде, \\ к.е.н., докторант, Інститут Економіки НАНА, м. Баку, Азербайджан
}

ОСНОВНІ ОСОБАИВОСТІ СУЧАСНОЇ РЕГІОНААЬНОЇ ПО ІТИКИ РОЗВИТКУ

The article considers the main features of ensuring regional development policy in a modern market economy. In this regard, the article examines the development trends of the states in terms of historical stages, shows that their development process was primarily related to the overall development of regional economic policy. From this point of view, it is necessary to pay more attention to the indicators of socio-economic development of the regions in the system of macroeconomic indicators, which play an important role in ensuring the sustainable development of the country. This problem is more relevant for the post-soviet countries. Based on the analysis, it was concluded that the effective implementation of regional development depends, first of all, on the correct definition of the main priorities of state regulation in this area.

Based on the analysis of the article, it is concluded that ensuring its balanced development in accordance with the real potential of the regions has a significant impact on increasing the competitiveness of the national economy. It should be noted that an important aspect of increasing the competitiveness of the national economy is related to the socio-economic development of the regions. It should be noted that ensuring the internal competitiveness of the economies of the regions depends on the degree of use of their resources in the balance, as well as the characteristics of the economic policy pursued by the state in this area. The experience of post-soviet countries shows that ensuring sustainable and balanced development of the regions makes it necessary to implement a national economic development strategy.

Achieving sustainable economic development in each country requires, first of all, the development of concept of an effective strategic development strategy. In the context of modern economic integration, ensuring the future development of the national economy is important.

At the same time, the article identifies the existing problems in ensuring modern regional development policy, as well as offers and recommendations for their elimination.

У статті розглянуто основні особливості забезпечення політики регіонального розвитку в сучасній ринковій економіці. У зв'язкуз цим у статті розглядається шлях розвитку держав з точки зору історичних етапів, видно, що процес їх розвитку був пов 'язаний насамперед із загальним розвитком регіональної економічної політики. 3 цієї точки зору необхідно більше уваги приділяти показникам соціально-економічного розвитку регіонів у системі макроекономічних показників, які відіграють важливу роль у забезпеченні сталого розвитку країни. Ця проблемає 
більш актуальноюдля пострадянських країн. На основі проведеного аналізу було зроблено висновок, що ефективне здійснення регіонального розвитку залежить насамперед від правильного визначення основних пріоритетів державного регулювання у цій галузі.

На основі аналізу статті зроблено висновок, що забезпечення його збалансованого розвитку відповідно до реального потенціалу регіонів має значний вплив на підвищення конкурентоспроможності національної економіки. Слід зазначити, що важливий аспект підвищення конкурентоспроможності національної економіки пов 'язаний із соціально-економічним розвитком регіонів. Забезпечення внутрішньої конкурентоспроможності економік регіонів залежить від ступеня використання їх ресурсів у балансі, а також від особливостей економічної політики, що проводиться державою в цій галузі. Досвід пострадянських країн показує, що забезпечення стійкого та збалансованого розвитку регіонів обумовлює необхідність реалізації стратегії національного економічного розвитку. Оцінка рівня економічного розвитку регіонів показала, що регіони не мають конкурентних переваг за кількома факторами.

Досягнення сталого економічного розвитку в кожній країні вимагає, передусім розробки багатогранної концепції ефективної стратегічної стратегії розвитку. В умовах сучасної економічної інтеграції важливимє забезпечення майбутнього розвитку національної економіки.

Водночас у статті визначено існуючі проблеми забезпечення сучасної політики регіонального розвитку, а також пропозиції та рекомендації щодо їх усунення.

Key words: macro-economy, state policy, integration, investment, economic integration, national economy.

Ключові слова: макроекономіка, державна політика, інтеграція, інВестиції, економічна інтеграція, національна економіка.

\section{INTRODUCTION}

In recent years, ensuring regional development policy in developed countries is one of the main priorities. It should be noted that in modern world practice there are different methodological approaches to the management of the regional economy. It should be noted that the diversity of approaches depends on the historical development characteristics of states, the nature of governance and economic mechanisms, levels of development, levels of participation in regional, regional and global integration processes, etc. explained by differences.

In the system of socialist governance, the main goal of the management of the regional economy was to make maximum use of the potential of each region to ensure the common economic interests of the country. In general, from an economic point of view, this was a very right step [1].

The beginning of the implementation of the strategy of harmonization of regional development levels in the 1990s, taking into account international experience in regional development policy in the last periods of the USSR's activity, confirmed the delay and importance of these processes.

Such an approach to the management of the regional economy was not considered effective in the transition of the newly independent post-soviet countries to a market economy after the collapse of the Soviet Union. The main reason for this is that in an economic system based on free market relations, the owner has an advantage in the acquisition of shares, or the principle of differential rent is considered to be adequate to the economic potential of each region.

\section{ANALYSIS OF RECENT PUBLICATIONS ON THIS TOPIC}

When approaching modern processes through the prism of a single economic space, it becomes clear that the potential of any region within a country in terms of use and utilization is not a full enclave. should also focus on ensuring. A.Sh.Shakaraliyev notes that in the context of modern economic integration, it is necessary to take into account the main development trends of the world economic system, the continuous evolution of the nature of the international division of labor due to innovation [1] [. In this case, it is possible by having a clearer idea of the reasons for the diversity of methodological principles and models of development of the regional economy in the context of the competitiveness of the national economy. K.N. Abdullayev notes that it is necessary to analyze theoretical ideas and progressive world experience in the management of the regional economy through the prism of the existing features of the modern market economy and to determine the methodological principles of its organization in a market economy [6]. In the experience of 
advanced developed countries, regional development policy is assessed as an effective activity that regulates socio-economic relations between the state and the regions and regions, and aims to ensure the dynamics of economic development of the country as a whole. D.V. Kuzmin shows in his scientific works that regional development policy should be approached as part of a sustainable national policy. In general, the structure of regional development policy includes: scientific and technical policy, environmental policy, settlement policy, demographic policy, social policy, economic policy, etc [5]. V.V. Mishenko, well-known in the post-soviet space, considers it necessary to classify regional development policy on the following criteria: targeting (regional government, firms and organizations are aimed at individual citizens); administrative measures (for example: permits and prohibitions); for the means and tools used (for example: economic measures - financial assistance, concessions, fines, etc.); according to the implementation mechanism (for example: normative distribution); purposeful (for example: equalization of the level of development of the regions) and etc [2].

\section{STATEMENT OF THE MAIN MATERIAL}

In general, based on international experience, it is expedient to conditionally divide the chronology of development of the methodological paradigm of regional economic management into the following stages:

- In the first stage, covering the 20 s and 40 s of the $X X$ century, the main principle of the management of the regional economy was the provision of emergency assistance to crisis areas in the world; the next stage, covering the 50 s and $70 \mathrm{~s}$ (XX century), is aimed at ensuring the balance of regional development by stimulating economic growth in certain regions on the basis of redistribution; in the third stage, covering the 70 s and 80 s ( $X X$ century), the main goal was to maximize the use of the internal potential of the regions, to support small and medium enterprises. In addition, it consisted of the restructuring of farms in the regions. in the XXI century, the main methodological principle of regional economic management is to transfer responsibility for the development of the regions to local governments, selfgovernment bodies and give them broad powers in order to realize the development potential that meets the interests of the regions. The modern regional development paradigm consists of social theories of regional development. In general, social theories of regional development are based on the mutual struggle of national and regional interests. This theory pays special attention to the distribution of political power and resources between the regions and the center, the problem of social differences [3]. Although the latter approach to the management of the regional economy in modern integration prevails in the world practice, postexpansionist theory that regulates interregional differences with the participation of the state by stimulating the flow of investment to economically underdeveloped regions. Theoretical approaches such as international practice of developed countries, more attention is paid to problem regions in the management of the regional economy. The main reason for this is that regional policy is based on a post-keynesian and unregulated market theory of unbalanced development that accepts the deepening of regional differences.

Research shows that in a market economy, the country's sustainable development policy and regional development policy must be mutually coordinated. At the same time, the country's socio-economic development policy should be aimed primarily at solving problems arising in order to achieve the set goals, as well as improving the welfare of the country's citizens. Regional development policy should ensure the effective realization of the development potential of the regions and the reduction of inter-regional disparities in terms of socio-economic development, taking into account local interests.

In the context of modern globalization, international economic relations play an important role in ensuring regional development in the country. The main reason for this is that in the last decade of the last century, as a result of radical changes in the world economic system (deepening of the international division of labor, accelerating the introduction of innovations, etc.), the role of external factors in the development of different countries and regions. Evidence of this can be seen in the recent development of liberalization policies around the world. This trend is more typical not only for the postsoviet countries, but also for the developed and developing countries of the world. The process of liberalization is already manifesting itself at the level of economic policy pursued in different countries, as well as international economic relations. It is widely accepted that the liberalization of international trade, investment and capital flows are a key factor in increasing the efficiency of the national economy and thus economic growth. It should be noted that in an open economic system, foreign economic relations, along with the development of the country's economy as a whole, are becoming factors that can have a strong impact on the development of domestic regions.

It should be taken into account that in order to achieve the maximum realization of the potential created by the advantages of the national economy in the international division of labor in the specific economic conditions. Regional development policy should be coordinated with foreign economic policy. The experience of developed countries shows that one of the most effective ways to ensure appropriate coordination is the implementation of comprehensive development programs within the country's regions.

Such programs provide for the proper specialization and integrated development of the economy of the regions with the proper use of local resources and potential. As a result, it ensures the realization of the potential created by the advantages of the country's economy in the international division of labor and, in particular, the acceleration of socioeconomic development of economic regions in the country.

A very important aspect of state regulation of regional development is related to ensuring social development. The regional policy of the state in this direction allows the development of traditional forms of economy in the regions by developing small businesses based on national customs and traditions, local raw materials [4].

In general, a very important aspect of ensuring the competitiveness of the national economy is related to the 
socio-economic development of individual economic regions. It should be noted that the provision of internal competitiveness in the regions depends on the balance of resources owned by each economic region and the level of their use, as well as the characteristics of economic policy formulated and implemented by the state. International experience shows that ensuring sustainable and balanced development of the regions, realization of its absolute and relative advantages, in turn, national economic development is formed by the interdependence of environmental, employment, agricultural, industrial, innovation, science and technology, investment policy with regional policy.

Systematic analysis and assessment of the level of economic development of the country's regions allows us to conclude that the country's regions do not have a competitive advantage on several factors. In general, the economic development of the regions requires a systematic and comprehensive approach to solving the problem, based not only on individual economic zones, but also on the wider area of production, technological, and reproduction dependencies [3].

\section{CONCLUSION}

Taking into account the above, based on international experience, it is expedient to formulate a methodological paradigm for the management of the regional economy as follows:

- management of economic activity in different regions, as well as the economic and financial mechanism is implemented through the application of vertical and horizontal models. In this case, the leadership of the vertical system must be ensured;

- one of the main tasks of the management of the regional economy should be to ensure that the interregional division of labor within the country is based on the principles of international division of labor, comparative advantages and mutual substitution of factors of production;

- the management of the regional economy should serve to ensure the effective realization of the economic potential of each region, with the appropriate distribution of powers between the central and local governments. Within the framework of regional policy, it should be ensured that the level of development of each region is adequate to its potential, and so on.

\section{Література:}

1. Шакаралиев А.Ш. Экономическая политика государства: торжество устойчивого и стабильного развития. - Баку: Изд. Victory, 2011. - 542 с.

2. Мищенко В.В. Экономика регионов. - Москва: ИК Аналитика, 2012. - 290 с.

3. Колесов В.П., Кулаков М.В. Международная экономика. - Москва: Инфрра-М, 2009. - 345 с.

4. Ширай В.И. Мировая экономика и международные экономические отношения. - Москва: Издательских дом Дашков и К, 2003. - 528 с.

5. Кузьмин Д.В. Национальная конкурентоспособность, глобальная нестабильность и макроэкономическое равновесие. - Москва: Наука, 2015. - 222 с.

6. Абдуллаев К.Н. The role of international transport corridors for providing sustainable development of national economy // Современная экономика и управле- ние: подходы, концепции, модели, Международная научно-практическая конференция, Российский экономический университет имени Г.В. Плеханова, Саратовский социально-экономический институт. - Саратов: Изд-во Наука, 2016. - С. 8-9.

\section{References:}

1. Shakaraliyev, A.Sh. (2011), Ekonomiceskaya politika qosudarstva: torjestva ustoycivoqo i stabilnoqo razvitiya [Economic policy of state: triumph of sustainable and stable development], Victory, Baku, Azerbaijan.

2. Mishenko, V.V. (2012), Ekonimika regionov [Economy of regions], IK Analitika, Moskva, Russia.

3. Kolesov, V.P. and Kulakov, M.B. (2009), Mejdunarodnaya ekonomika [International economics], Infra, Moskva, Russia.

4. Shiray, V.I. (2003), Mirovaya ekonomika i mejdubarodnie ekonomiceskie otnosheniya [World economy and international economic relations], Moskva, Dashkov and K, Moskva, Russia.

5. Kuzmin, D.V. (2015), Nasionalnaya konkurentosposobnost, qlobalnaya nestabilnost i makroekonomiceskie ravnovesii [National competitiveness, global unstability and macroeconomic balance], Nauka, Moskva, Russia.

6. Abdullayev, K.N. (2016), "The role of international transport corridors for providing sustainable development of national economy", Sovremennaya ekonomika I upravlenie : podxodi, konsepsii, modeli. Mejdunarodnaya naucno-prakticeskaya konferensiya [Modern economy: approach, conceptions, models. International scientificpractical conference], Rossiyskoy Ekonomiceskiy Universitet imeni Q.V.Plexanova (Moscow), Russian Economic University after named Q.V.Plexanova, Saratovskiy Sosialno-Ekonomiceskoy Institut (Saratov), Saratov Social Economic Institute, Saratov, Russia, pp. 8-9.

Стаття надійшла до редакиї 09.03.2021 p.

\section{www. economy.nayka.com.ua}

Електронне фахове видання

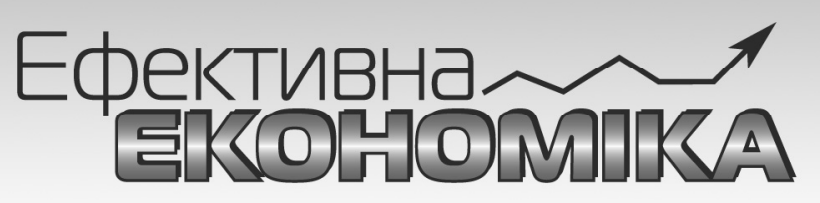

\section{Виходить 12 разів на рік}

Хурнал включено до переліку наукових фахових видань України з ЕКОНОМІЧНИХ НАУК (Категорія «Б»)

Спеціальності - 051, 071, 072, 073, 075, 076, 292

e-mail:economy_2008@ukr.net

тел.: (044) 223-26-28

(044) $458-10-73$ 